\title{
Metal Complexes of Proline-Azo Dyes, Synthesis, Characterization, Dying Performance and Antibacterial Activity Studies
}

\author{
ALYA KHIDER ABBAS* and RAFAL SALAM KADHIM \\ Department of Chemistry, College of Science, University of Baghdad, Baghdad, Iraq. \\ ${ }^{*}$ Corresponding author E-mail: rafalsalam257@yahoo.com \\ http://dx.doi.org/10.13005/ojc/330148
}

(Received: August 03, 2016; Accepted: January 13, 2017)

\begin{abstract}
The synthesis, structural spectroscopic properties of 4-(2-benzimidazolylazo)proline (BMP) and its complexes derived from $[\mathrm{Cu}(\mathrm{II}), \mathrm{Ag}(\mathrm{I})$ and $\mathrm{Au}(\mathrm{III})]$ salts were done. The mode of bonding for the complexes were accomplished based on elemental analysis, FTIR, UV-Vis and HNMR spectroscopy, magnetic measurement and molar conductivity. It has been found that the ligand (BMP) behaves as N,N-neutral bidentate which was forming chelates with molar ratio (1:2) (M:L) stoichiometry for $[\mathrm{Cu}(\mathrm{II})$ and $\mathrm{Ag}(\mathrm{I})]$ while $\mathrm{Au}(\mathrm{III})$ complex form molar ratio (1:1) at optimum concentration and $\mathrm{pH}$ as well as $\left(\lambda_{\max }\right)$. The stability constant and Gibbs free energy for the prepared complexes are evaluated by spectroscopic methods. The prepared ligand (BMP) in comparison to its metal complexes, were screened for their antibacterial activity against two bacterial species, Escherichia coli and Staphylococcus. Dying performance was also studied.
\end{abstract}

Keywords: Azo dyes, azo complexes, synthesis.

\section{INTRODUCTION}

The expansions of new structure of azo compounds have been a subject of regard and much novel structure of these compounds ${ }^{1}$. Azo compounds with the hetrocyclic diazo component from colored complexes with universality metal ions ${ }^{2}$ and are an important for industry and biological system $^{3}$. In addition metal chelates have been studies and attracted much attention due to their interesting electronic and geometrical features in connection with their application various fields ${ }^{4}$. This type of azo compounds which are characterized with ( -acidic) azo imine (-N=N-C-N) which giving results with good rates and great stability as well as characterized with ease of purification and deep colors which have displacements in the wavelength when they are consistent with transition metal ions $^{5,6}$. The chelate complexes that have fivemembered or six-membered chelate rings are the most stable complexes ${ }^{7}$. In the fact that some drugs including discouraging the growth of germs $^{8,9}$. In addition, the important uses of these compounds are analytical reagents ${ }^{10-12}$ for solvent 
extraction to determine some metal ions. The azo imidazole compounds have important role in spectral determination field to identify the amount of elements especially with transition metal ions because of its sensitivity and selectivity ${ }^{13}$. In our research we were able to prepare new ligand (BMP) and its complexes with $[\mathrm{Cu}(\mathrm{II}), \mathrm{Ag}(\mathrm{I})$ and $\mathrm{Au}(\mathrm{III})]$ taking into account a spectral study in order to obtain optimum condition (concentration and $\mathrm{pH}$ ) and metal to ligand ratio for preparation the complexes.

\section{EXPERIMENTAL}

\section{Materials and Instruments}

All elements and solvent are of best purity and used as found from the productions. Microelemental analysis (C.H.N) was gained on a (Eure EA 3000 Elemental analyzer). UV-Vis Spectra were performed in ethanol on a (Shimadz UV-160A) ultra violet-visible spectrophotometer. FTIR-spectra were recorded on a (Shimadz FTIR-8400s Fourier Transform Infrared) spectrophotometer (2004000) $\mathrm{cm}^{-1}$ using CsI discs. The ${ }^{1} \mathrm{HNMR}$ spectra were gained on a ( ${ }^{1} \mathrm{HNMR}$ Spectrometer 4000 $\mathrm{MHz}$, Avance III 400 Bruker, Germany". The molar Conductivity for the complexes was determined in $\left(10^{-3} \mathrm{M}\right)$ DMSO at room temperature using (HANNA instruments / Conductivity Tester). $\mathrm{pH}$ measurement was performed using (HANNA instruments $\mathrm{pH}$ Tester / Pocket $\mathrm{pH}$ Tester). Melting points have been gained via using (Stuart Melting Point Apparatus). The percentage of metal in complexes was done by using a "GBC 933 plus "Flam Atomic Absorption Spectrophotometer. Thermal Analysis measurements TG, DTG and DSC were performed by using (Mettler) Thermogravimetric Analyzer.

\section{Synthesis of 4-[(2- benzimidazolyl )azo] proline (BMP)}

This ligand was synthesized according to the method reported in the literature ${ }^{14}$ with some modifications as shown in scheme (1):

\section{Preparation of solutions}

Ammonia acetate as a buffer solution was prepared with a range (5-9) by dissolving (0.01 $\mathrm{M}, 0.77 \mathrm{gm}$ ) in one litter of deionized water. $\mathrm{pH}$ was detected by adding acetic acid or ammonia solution. As for standard solutions for selected metal salts and ligand were prepared by dissolving appropriate weight to the extent $\left(1 \times 10^{-5} \mathrm{M}-3 \times 10^{-5} \mathrm{M}\right)$.

\section{Synthesis of complexes}

Three complexes were prepared via adding regularly with stirring hot ethanolic solution of (2 mmole) ligand to stoichiometry mole ratio of (1:2) $(\mathrm{M}: \mathrm{L})$ for $[(\mathrm{Cu}(\mathrm{II})$ and $(\mathrm{Ag}(\mathrm{I})]$ and $(1: 1)$ for $[\mathrm{Au}(\mathrm{III})]$ which were dissolved in the prepared buffer solution at optimum $\mathrm{pH}$. Then the mixture was heated to $\left(60^{\circ} \mathrm{C}\right)$ with stirring for $3 \mathrm{~h}$, after that left to cool at room temperature. The colored precipitates were filtered, washed and desiccated in vacuum desiccator. The suggested stoichiometry structure of the prepared complexes is shown in scheme (2).

\section{RESULTS AND DISCUSSIONS}

The reaction of the prepared ligand (BMP) with selected transition metal ions [Cu(II), $\mathrm{Ag}(\mathrm{I})$ and $\mathrm{Au}(\mathrm{III})$ ] at optimum $\mathrm{pH}$ and concentration, which mains to formation of the complexes with following formula $\left[\mathrm{Cu}(\mathrm{BMP})_{2} \mathrm{Cl}_{2}\right],\left[\mathrm{Ag}(\mathrm{BMP})_{2}\right] \mathrm{NO}_{3}$ and $\left[\mathrm{Au}(\mathrm{BMP}) \mathrm{Cl}_{2}\right] \mathrm{Cl}$. The ligand (BMP) doings as N, N'chelator, where $\mathrm{N}$ of (azo) and N' of (benzimidazole). The structure of the complexes is supported via the analytical and spectral studies results. All complexes were stable in air and moisture as well as soluble in most organic solvents such as ethanol, DMSO, DMF, acetone ...etc. By studying the molar conductivity of the prepared complexes which were measured at $\left(10^{-3} \mathrm{M}\right)$ in DMSO found that $\mathrm{Cu}$ (II) complex was non electrolyte while $\mathrm{Ag}(\mathrm{I})$ and $\mathrm{Au}(\mathrm{III})$ complexes are (1:1) electrolyte, supporting the ionic behavior for $\mathrm{Ag}(\mathrm{I})$ and $\mathrm{Au}(\mathrm{III})$ complexes, (Table (1)).<smiles>CC(C)[C@H](C)c1ccc2[nH]c([N+]#N)nc2c1</smiles>

Scheme (1): Preparation of BMP ligand 
The UV-Vis spectra of the prepared ligand (BMP) and its complexes under examination as was shown in Figures (1 and 2) were shown mainly two peaks observed in ethanol $\left(10^{-4}\right)$ within the range (250-1100) $\mathrm{nm}$. The first peak at (339) $\mathrm{nm}$ for ligand (BMP) was owing to the $\pi \rightarrow \pi^{\star}$ transition of the aromatic rings. The second peak $\left(\lambda_{\max }\right)$ at (449) $\mathrm{nm}$ ligand (BMP) was related to the $\pi \rightarrow \pi^{\star}$ this is assigned to the transition of (GT) intramolecular charge-transfer taken place through the azo moiety $(-\mathrm{N}=\mathrm{N}-)^{15}$.

It has been saw red shift in the visible region when a competitive study between the spectra of mixing aqueous solutions for [ $\mathrm{Cu}(\mathrm{II}), \mathrm{Ag}(\mathrm{I})$ and $\mathrm{Au}(\mathrm{III})$ ] with ethanolic solutions of ligand (BMP) which ranged between (250-1100)nm. The change in the appearance color of free ligand (BMP) solution and high shift in the $\left(\lambda_{\max }\right)$ gives a good sign for coordination and formation of complexes.

On the other hand the UV-Vis spectra were studied for mixed solutions of [Cu(II), $\mathrm{Ag}(\mathrm{I})$ and $\mathrm{Au}(\mathrm{III})$ ] and ligand (BMP) within the range of concentration from $\left(10^{-3} \mathrm{M}-10^{-6} \mathrm{M}\right)$, only $10^{-5}$ obey Lambert Beer low, while the $\mathrm{pH}$ sequence was from (5-9). Figure (3) was appeared best suitable straight lines, with correlation factor $(r>0.989)$ when the absorbance plotted against molar concentration in the rang from $\left(1 \times 10^{-5} \mathrm{M}-3 \times 10^{-5} \mathrm{M}\right)$.

The $\mathrm{pH}$ effect was also examined at the range (5-9). Figure (4) was shown the absorbance$\mathrm{pH}$ curves which are completed at $\left(\lambda_{\text {max }}\right)$ and various
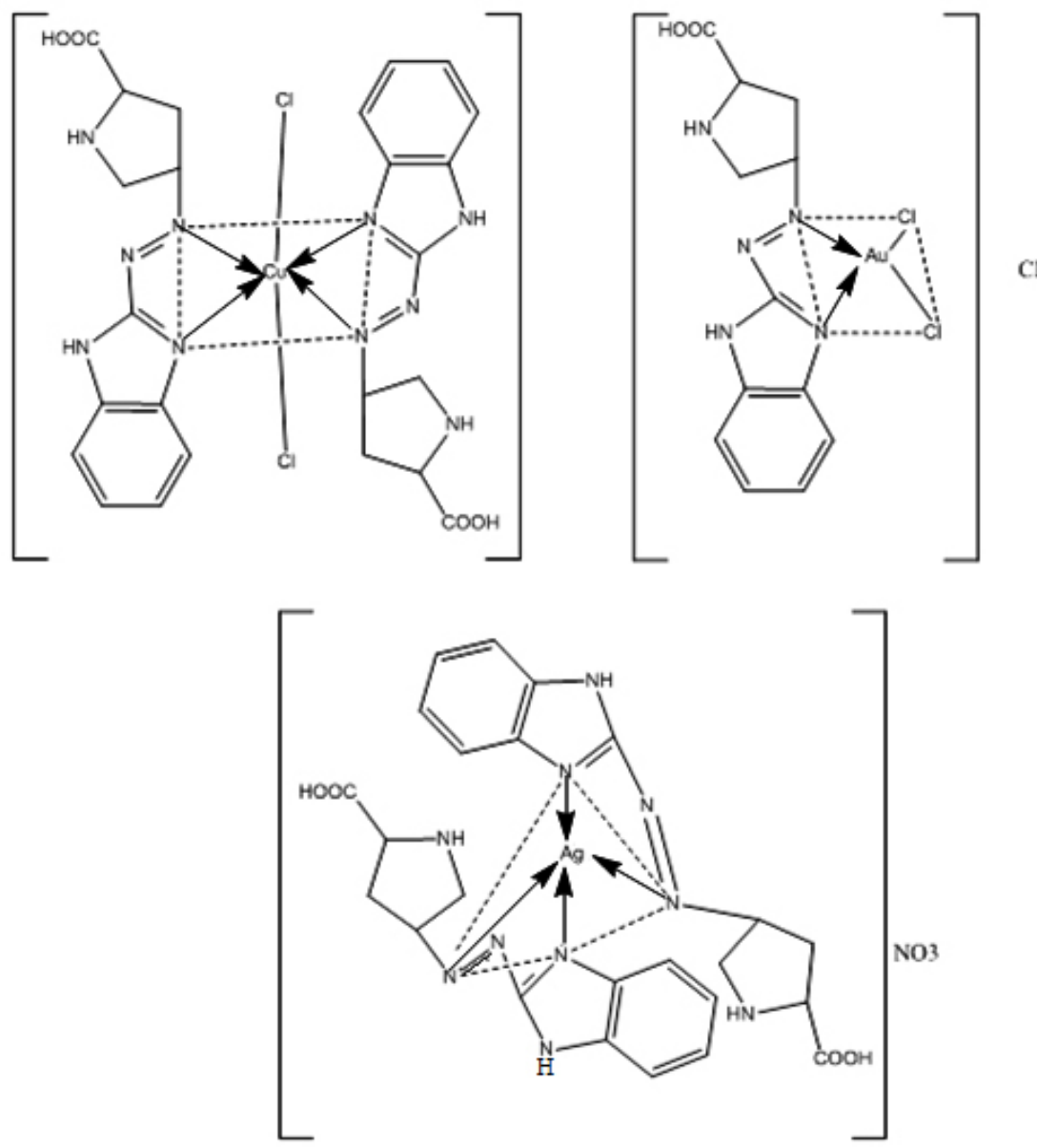

Scheme (2): The suggested structure for the prepared complexes 
concentrations for each metal ion solution under study. A high band on the $\mathrm{pH}$ curves it is considered as a mark of the complex formation and acceptance as optimum $\mathrm{pH}$ for all preparation complexes. But the descent part of the curves may be referring to the dissociation of complex at this point. Therefore, we conclude that all prepared chelate complexes with selected metal ions are formed in neutral or basic medium $^{16,17}$ :

Spectrophotometry is one of the most useful tools for elucidation of the composition of complexes in solution. The power of the technique lies in the fact that quantitative absorption measurements can be performed without fear of disturbing the equilibria under consideration. Two of the most common techniques employed for identify the composition of the complexes in solution without isolation are the mole ratio procedure and continuous variations method or Job method ${ }^{18}$ (Figures (5 and 6)):

The two methods support same result about mole ratio of the complexes. It will be taking into account all the result we have obtained to install optimal condition to prepare the complexes of [Cu(II), $\mathrm{Ag}(\mathrm{I})$ and $\mathrm{Au}(\mathrm{III})]$ with the ligand (BMP).

Determination of Stability Constant and Gibbs free energy of prepared complexes:-

The stability constant $(\mathrm{K})$ for $\mathrm{Cu}(\mathrm{II})$ and $\mathrm{Ag}(\mathrm{I})$ complexes in a mole ratio (M:L)(1:2) was computed based on the equation ${ }^{19}$.

Table 1: physiochemical properties, elemental analysis, mole ratio, molar conductance for the ligand (BMP) and selected metal ions

\begin{tabular}{|c|c|c|c|c|c|c|c|c|}
\hline \multirow{2}{*}{$\begin{array}{l}\text { Complexes } \\
\text { (M.wt) } \\
\text { (gm/mol) }\end{array}$} & \multirow{2}{*}{$\begin{array}{c}\text { pH } \\
(\mathrm{M}: L)\end{array}$} & \multirow{2}{*}{$\begin{array}{l}\text { Color } \\
\lambda(\mathrm{nm})\end{array}$} & \multirow[b]{2}{*}{ C } & \multicolumn{4}{|c|}{$\%$ Found \% (Calculated) } & \multirow{2}{*}{$\begin{array}{c}\Lambda \\
\left(\mathrm{S} . \mathrm{mol}^{-1} \mathbf{c m}^{2}\right)\end{array}$} \\
\hline & & & & $\mathbf{H}$ & $\mathbf{N}$ & $\mathbf{M}$ & Cl ( & \\
\hline $\begin{array}{l}\left.\mathrm{BMP}) \mathrm{C}_{12} \mathrm{H}_{13} \mathrm{~N}_{5} \mathrm{O}_{2}\right) \\
(260.13)\end{array}$ & - & $\begin{array}{l}\text { Yellow- } \\
\text { green }\end{array}$ & $\begin{array}{c}56.87 \\
(56.907)\end{array}$ & $\begin{array}{c}5.38 \\
(5.471)\end{array}$ & $\begin{array}{c}25.47 \\
(25.535)\end{array}$ & - & - & - \\
\hline $\begin{array}{l}{\left[\mathrm{Cu}\left(\mathrm{C}_{24} \mathrm{H}_{26} \mathrm{~N}_{10} \mathrm{O}_{4}\right) \mathrm{Cl}_{2}\right]} \\
(654.8)\end{array}$ & $\begin{array}{c}7 \\
(1: 2)\end{array}$ & $\begin{array}{c}\text { Blue- } \\
\text { violet(610) }\end{array}$ & $\begin{array}{c}44.79 \\
(44.02)\end{array}$ & $\begin{array}{c}4.43 \\
(3.97)\end{array}$ & $\begin{array}{c}20.77 \\
(21.70)\end{array}$ & $\begin{array}{c}9.77 \\
(9.70)\end{array}$ & $\begin{array}{c}10.91 \\
(10.84)\end{array}$ & 10 \\
\hline $\begin{array}{l}{\left[\mathrm{Ag}\left(\mathrm{C}_{24} \mathrm{H}_{26} \mathrm{~N}_{10} \mathrm{O}_{4}\right)\right] \mathrm{NO}_{3}} \\
(690.13)\end{array}$ & $\begin{array}{c}8.5 \\
(1: 2)\end{array}$ & $\begin{array}{c}\text { Red } \\
(497)\end{array}$ & $\begin{array}{c}40.66 \\
(41.73)\end{array}$ & $\begin{array}{c}4.19 \\
(3.76)\end{array}$ & $\begin{array}{c}22.71 \\
(22.31)\end{array}$ & $\begin{array}{c}15.60 \\
(15.63)\end{array}$ & - & 34 \\
\hline $\begin{array}{l}{\left[\mathrm{Au}\left(\mathrm{C}_{12} \mathrm{H}_{13} \mathrm{~N}_{5} \mathrm{O}_{2}\right) \mathrm{Cl}_{2}\right] \mathrm{Cl}} \\
(563.6)\end{array}$ & $\begin{array}{c}8 \\
(1: 1)\end{array}$ & $\begin{array}{l}\text { Red } \\
(496)\end{array}$ & $\begin{array}{c}25.43 \\
(25.55)\end{array}$ & $\begin{array}{c}2.19 \\
(2.129)\end{array}$ & $\begin{array}{c}11.97 \\
(12.42)\end{array}$ & $\begin{array}{c}34.90 \\
(34.94)\end{array}$ & $\begin{array}{c}18.99 \\
(18.89)\end{array}$ & 35 \\
\hline
\end{tabular}

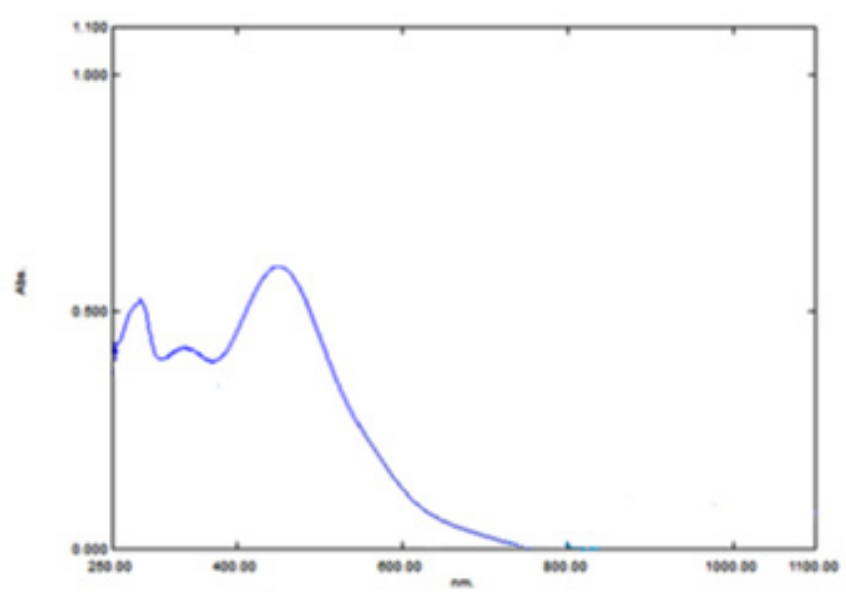

Fig. 1: UV-Vis spectrum of the ligand (BMP) 
$\mathrm{K}=\frac{1-\alpha}{4 \alpha^{3} \mathrm{C}^{2}}$

As for the stability constant for Au(III) complex in a mole ratio (M:L) $(1: 1)$ was computed based on the equation ${ }^{19}$ :

$\mathrm{K}=\frac{1-\alpha}{\alpha^{2} \mathrm{C}}$

Where:

$\alpha=\frac{\mathrm{Am}-\mathrm{As}}{\mathrm{Am}}$ $\alpha=$ degree of dissociation.

$\mathrm{Am}=$ the absorption of solution containing the same volume of metal and excess of ligand.

As $=$ the absorption of solution containing a stoichiometric volume of ligand and metal ion.

$\mathrm{C}=$ the concentration of the complex solution in mole/ L.

From Table (3) we calculated that $\mathrm{Cu}$ (II) and $\mathrm{Ag}(\mathrm{I})$ complexes more stable than $\mathrm{Au}(\mathrm{III})$ complex. The thermodynamic parameters of Gibbs free energy $(\Delta G)$ were also studied. The $\Delta G$ data have been calculated from the equation below ${ }^{20}$ :

$$
\Delta \mathrm{G}=-\mathrm{R} T \ln \mathrm{k}
$$

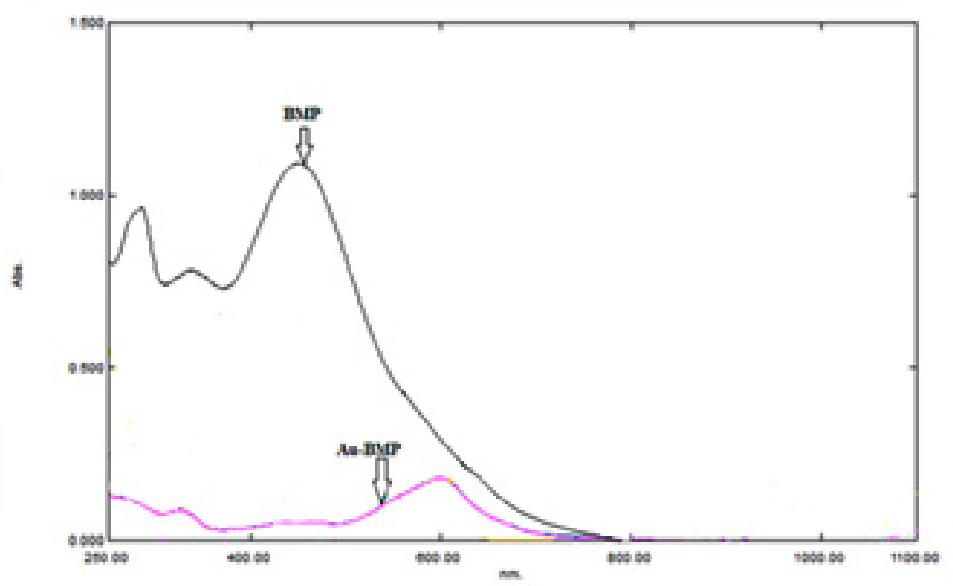

Fig. 2: UV-Vis spectra of the ligand BMP and Au-BMP complexes solution

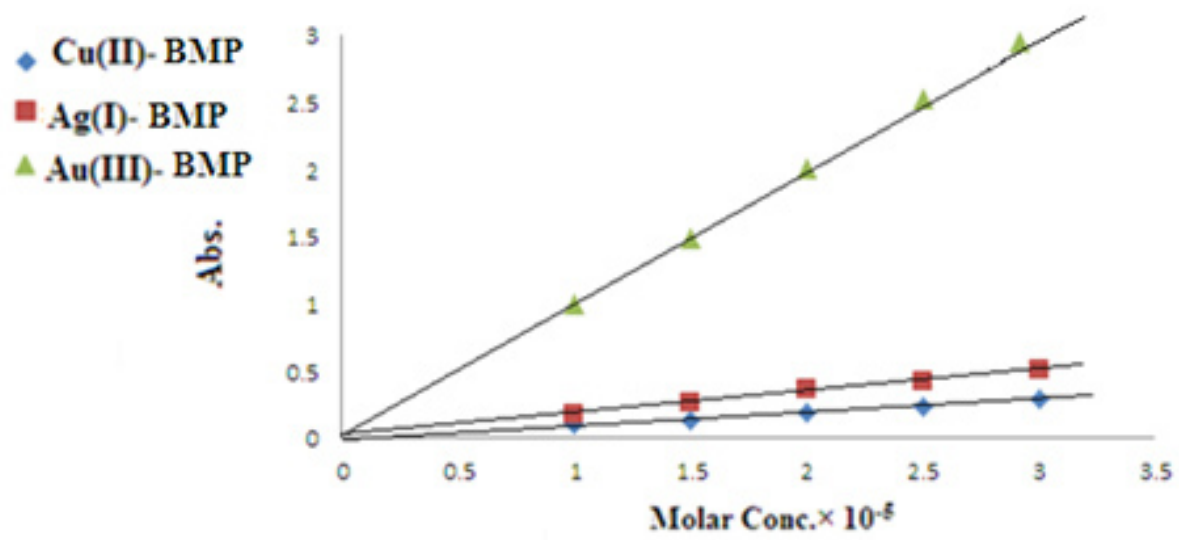

Fig. 3 : Linear relationship between molar concentration and absorbance for metal ion-BMP complexes solution at optimum $\mathrm{pH} \& \lambda_{\max }$ 
Where $\mathrm{R}=$ gas constant $=8.3 \mathrm{~J} \cdot \mathrm{mol}^{-1} \cdot \mathrm{K}, \mathrm{T}$ $=$ absolute temperature (Kelvin).

Table (3) was shown that the formations of all prepared complexes are spontaneous.
Electronic Spectra and Magnetic measurement for solid complexes

The UV-Vis absorption spectra of the coordination compounds provide a convenient method for determining the magnitude of the effect

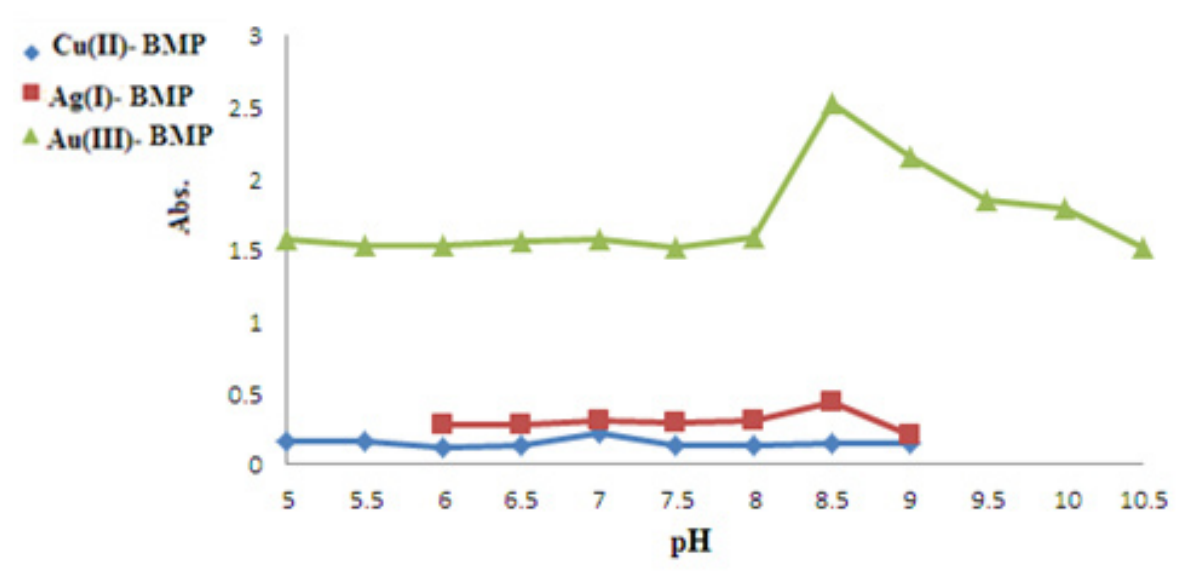

Fig. 4: Effect of $\mathrm{pH}$ on absorbance at $\lambda_{\max }$ for metal ions-BMP complexes solution

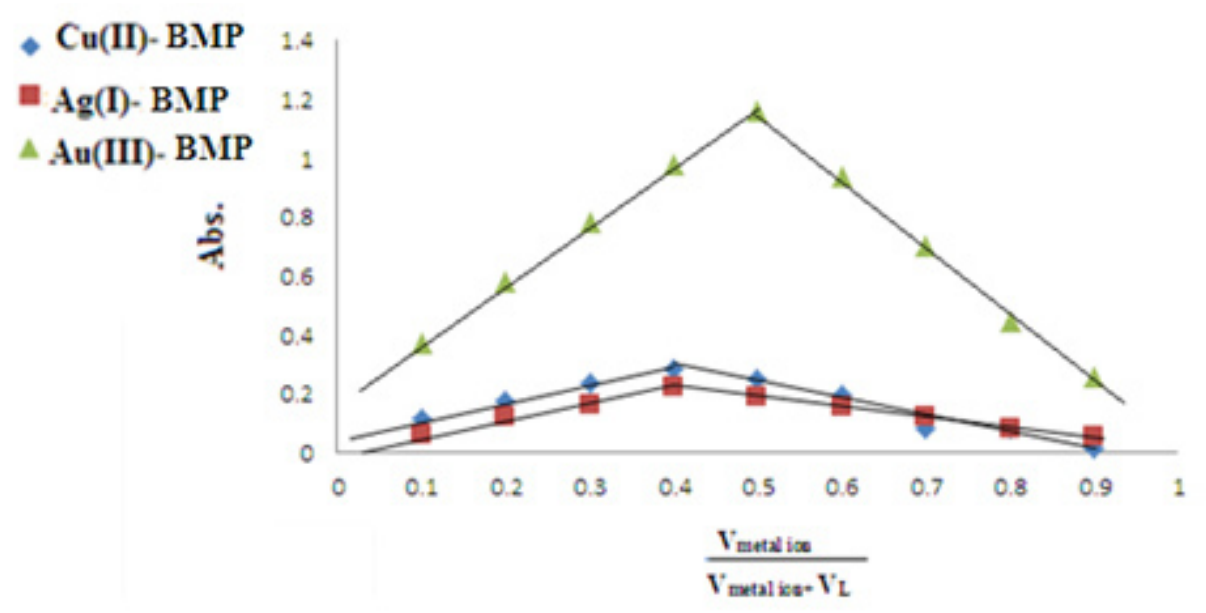

Fig. 5: Job Method plot of metal ion-BMP ligand complexes solution at optimum pH and $\lambda_{\max }$

Table 3: Stability constant $(\mathrm{K})$ and Gibbs free energy $(\Delta \mathrm{G})$ for the prepared complexes

\begin{tabular}{lcccccc}
\hline Complexes & Am & As & $\alpha$ & K & Log K & $\Delta \mathbf{G}$ \\
\hline$\left[\mathrm{Cu}(\mathrm{BMP})_{2} \mathrm{Cl}_{2}\right]$ & 0.304 & 0.155 & 0.4901 & $1.7325 \times 10^{9}$ & 9.23869 & -52969.47322 \\
{$\left[\mathrm{Ag}(\mathrm{BMP})_{2}\right] \mathrm{NO}_{3}$} & 0.194 & 0.100 & 0.4845 & $1.8130 \times 10^{9}$ & 9.25842 & -53082.57391 \\
{$\left[\mathrm{Au}(\mathrm{BMP}) \mathrm{Cl}_{2}\right] \mathrm{Cl}$} & 0.532 & 0.175 & 0.6710 & $2.9228 \times 10^{4}$ & 4.4658 & -25604.44463 \\
\hline
\end{tabular}




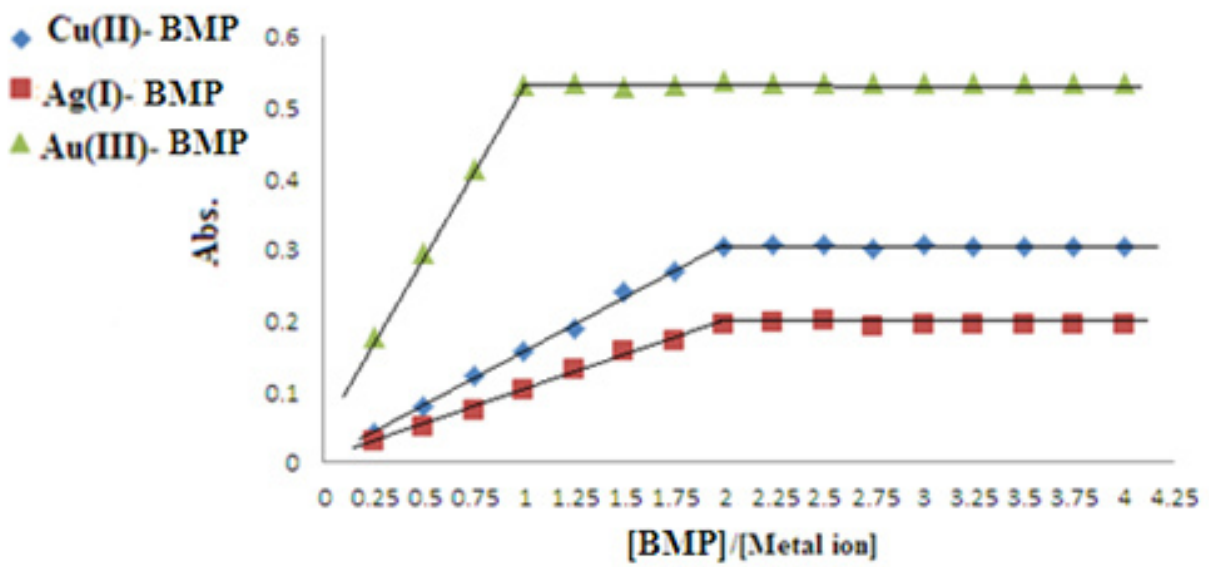

Fig. 6: Mole ratio plot for metal ion-BMP complex solution at optimum $\mathrm{pH}$ and $\lambda_{\max }$

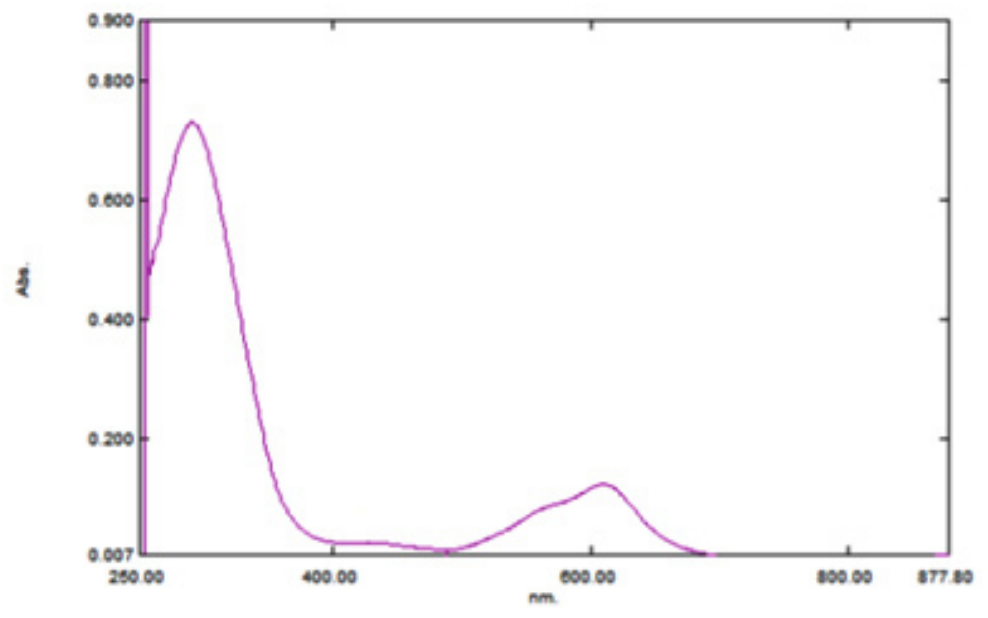

Fig. 7: UV-Vis spectrum of the Cu-BMP complex

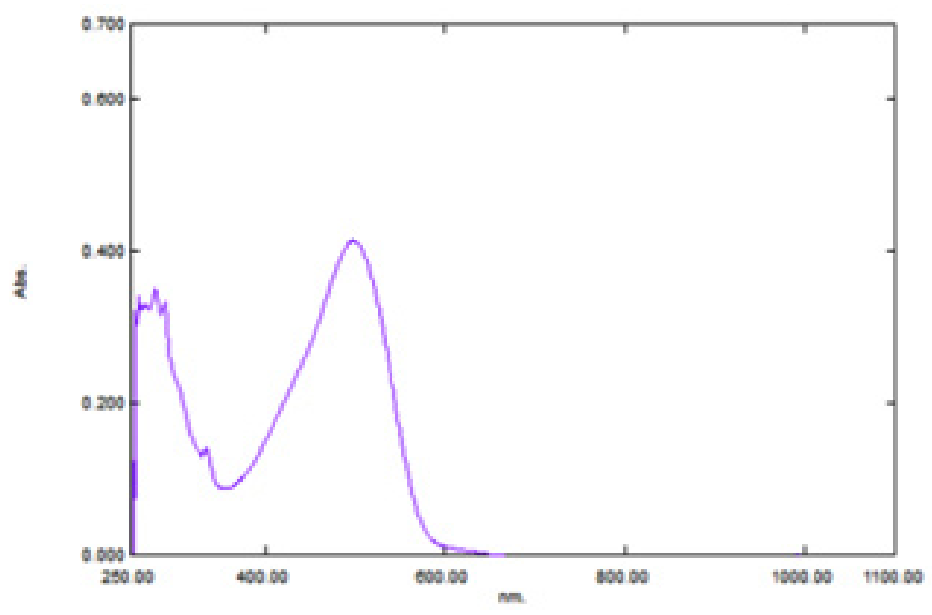

Fig. 8: UV-Vis spectrum of the Ag-BMP complex 
of ligand filed on the d-orbitals of the metal ions. The UV-Vis spectrum of Cu-Complex with ligand (BMP) was shown in Figure (7) showed three absorption bands. The first band looked at (610) nm, (16393) $\mathrm{cm}^{-1}$. This is assigned to the transition $\left({ }^{2} \mathrm{~B}_{1} \mathrm{~g} \rightarrow\right.$ ${ }^{2} A_{1} g$ ). The second band was observed at (427) $\mathrm{nm}$, (23419) $\mathrm{cm}^{-1}$ which is assigned to the transition $\left({ }^{2} \mathrm{~B}_{1} \mathrm{~g} \rightarrow{ }^{2} \mathrm{~B}_{2} \mathrm{~g}\right)$. The third band at (291) $\mathrm{nm}$ (34362) $\mathrm{cm}^{-1}$ and was assigned to C.T transition. These three transitions characterized distorted octahedral $\left(d^{9}\right)$ geometry $D_{4} h^{21}$. With paramagnetic properties (Table (4)).

As for the Ag-complexes $\left(d^{10}\right)$, one absorption band at (497) $\mathrm{nm}(20120) \mathrm{cm}^{-1}$ which is related to $\left(\pi \rightarrow \pi^{\star}\right)$ (MLCT) transition (Figure (8)). These complexes are to be tetrahedral ${ }^{22}$. The magnetic properties are diamagnetic for Agcomplexes (Table (4)).

Recently the UV-Vis spectrum for Aucomplexes $d^{8}$ low spin square planer structure, was appeared (d-d) transition. The $\left[\mathrm{Au}(\mathrm{BMP}) \mathrm{Cl}_{2}\right] \mathrm{Cl}$ have four absorption bands at $(980,861,653$ and 496)nm (10204, 11614, 15313 and 20161) $\mathrm{cm}^{-1}$ which are due to transition of ${ }^{1} A_{1} g \rightarrow{ }^{2} A_{2} g,{ }^{1} A_{1} g \rightarrow{ }^{1} E g,{ }^{1} A_{1} g \rightarrow{ }^{1} A_{2} u$ and ${ }^{1} A_{1} g \rightarrow{ }^{1} B_{1} g$ respectively as was shown in (Figure $(9))^{23}$. With diamagnetic properties (Table (4)).

IR Spectra of prepared Ligands and Complexes

For identification and detect the coordination site that may be involved in complexation. The FTIR spectra of all prepared complexes using Csl were compared with the prepared ligand (BMP) (Figures

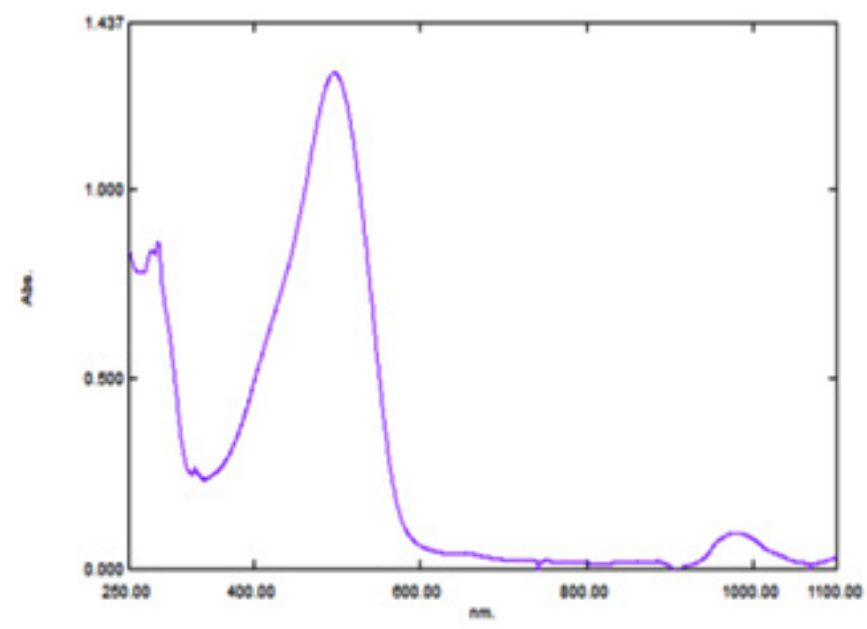

Fig. 9: UV-Vis spectrum of the Au-BMP complex

Table 4: The UV-Vis spectra for the prepared complexes at $\left(10^{-4} \mathrm{M}\right)$

\begin{tabular}{lccccc}
\hline Compounds & $\lambda \mathbf{n m}$ & $\begin{array}{c}\text { Wave } \\
\text { Number } \mathbf{c m}^{-1}\end{array}$ & $\begin{array}{c}\varepsilon_{\mathrm{o}} \times 1 \mathbf{1 0}^{4} \\
\mathrm{~L} \cdot \mathbf{m o l}^{-1} \cdot \mathbf{c m}^{-1}\end{array}$ & Assignment & $\begin{array}{c}\text { Magnetic } \\
\text { properties }\end{array}$ \\
\hline & 610 & 16393 & 0.124 & ${ }^{2} \mathrm{~B}_{1} \mathrm{~g} \rightarrow{ }^{2} \mathrm{~A}_{1} \mathrm{~g}$ & Paramagnetic \\
& 427 & 23419 & 0.028 & ${ }^{2} \mathrm{~B}_{1} \mathrm{~g} \rightarrow{ }^{2} \mathrm{~B}_{2} \mathrm{~g}$ & \\
{$\left[\mathrm{Cu}(\mathrm{BMP})_{2} \mathrm{Cl}_{2}\right]$} & 291 & 34362 & 0.731 & $\mathrm{MLCT}$ & \\
{$\left[\mathrm{Ag}(\mathrm{BMP})_{2}\right] \mathrm{NO}_{3}$} & 497 & 20120 & 0.414 & $\pi \rightarrow \pi \pi^{*}(\mathrm{MLCT})$ & Diamagnetic \\
& 980 & 10204 & 0.096 & ${ }^{1} \mathrm{~A}_{1} \mathrm{~g} \rightarrow{ }^{2} \mathrm{~A}_{2} \mathrm{~g}$ & Diamagnetic \\
& 861 & 11614 & 0.018 & ${ }^{1} \mathrm{~A}_{1} \mathrm{~g} \rightarrow{ }^{1} \mathrm{Eg}$ & \\
{$\left[\mathrm{Au}(\mathrm{BMP}) \mathrm{Cl}_{2}\right] \mathrm{Cl}$} & 653 & 15313 & 0.040 & ${ }^{1} \mathrm{~A}_{1} \mathrm{~g} \rightarrow{ }^{1} \mathrm{~A}_{2} \mathrm{u}$ & \\
& 496 & 20161 & 1.305 & ${ }^{1} \mathrm{~A}_{1} \mathrm{~g} \rightarrow{ }^{1} \mathrm{~B}_{1} \mathrm{~g}$ & \\
\hline
\end{tabular}


(10-13)). The spectra of the prepared complexes presented the bands specific to the ligand with some differences in the shape and positions of the bands mention to the formation and coordination of complex, Table (5) induced the main infrared spectral bands of the free ligand and its complexes.

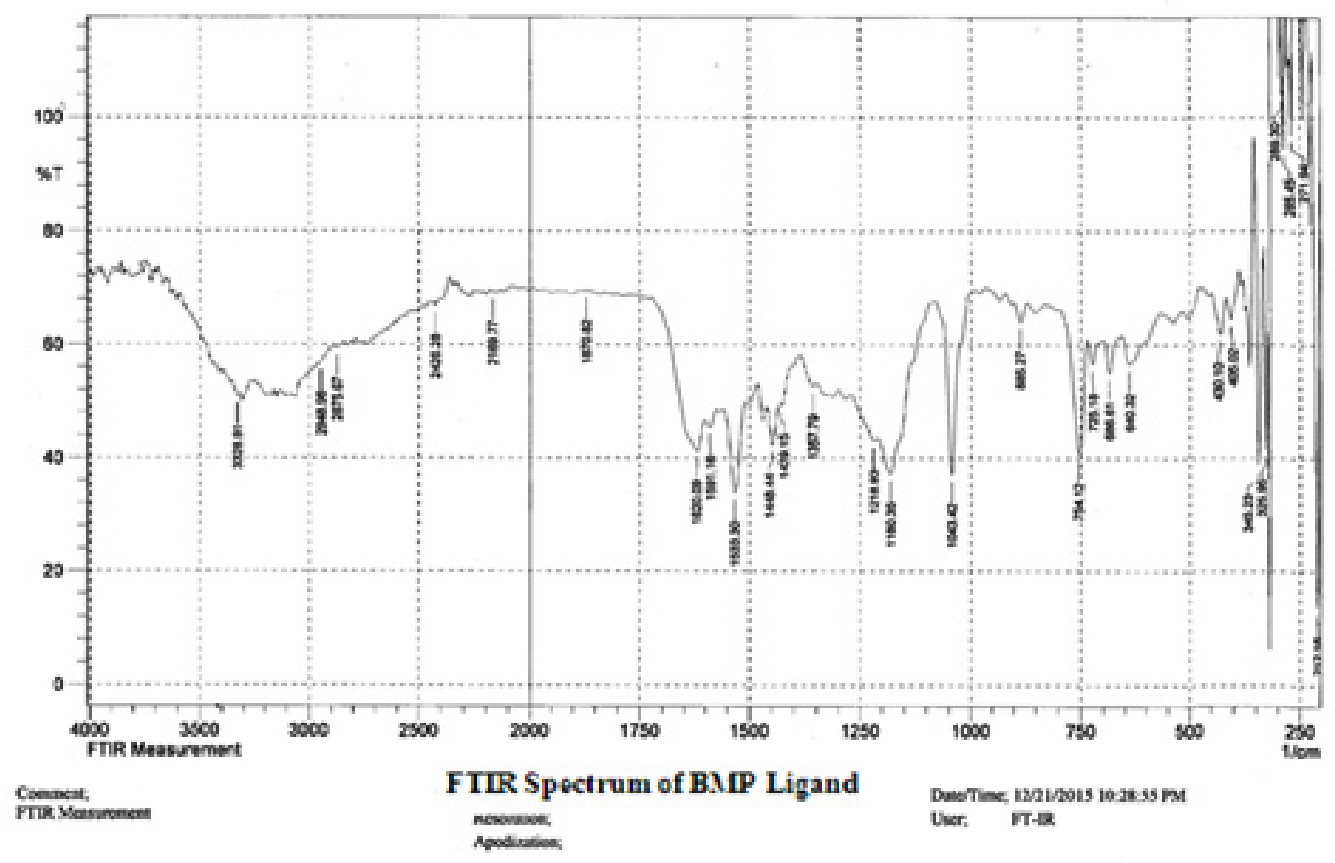

Fig. 10: FTIR spectrum of BMP ligand

Table 5: Main band of FTIR for the ligand (BMP) and its Complexes

\begin{tabular}{|c|c|c|c|c|}
\hline Compound & BMP & {$\left[\mathrm{Cu}(\mathrm{BMP})_{2} \mathrm{Cl}_{2}\right]$} & {$\left[\mathrm{Ag}(\mathrm{BMP})_{2}\right] \mathrm{NO}_{3}$} & {$\left[\mathrm{Au}(\mathrm{BMP}) \mathrm{Cl}_{2}\right] \mathrm{Cl}$} \\
\hline$v\left(\mathrm{~N}-\mathrm{H}_{\text {Pro. }}\right)$ & 3328 w.b & $3357 w$ & $3335 w$ & $3336 w$ \\
\hline$v(\mathrm{O}-\mathrm{H})$ in $\mathrm{COOH}$ & 3440 w.b. & $3442 m$ & $3423 w$ & $3434 w$ \\
\hline$v\left(\mathrm{~N}-\mathrm{H}_{\mathrm{imd}} \cdot\right)$ & $3128 m$ & $3125 w$ & $3125 w$ & $3126 w$ \\
\hline$v\left(\mathrm{C}-\mathrm{H}_{\mathrm{Ar}}\right)$ & $3056 w$ & $3056 \mathrm{~m}$ & $3055 \mathrm{~m}$ & 3053 \\
\hline$v(C=N)$ & $1620 \mathrm{~d}$. & $1606 \mathrm{~d}, \mathrm{~m}$ & 1616 d., s & $1623 \mathrm{~d}, \mathrm{~m}$ \\
\hline & $1591 \mathrm{~m}$ & 1580 & 1604 & 1593 \\
\hline$v(\mathrm{~N}=\mathrm{N})$ & $\begin{array}{c}1450 \mathrm{t} . \\
1448 \mathrm{~m} \\
1429\end{array}$ & $\begin{array}{c}1429 \mathrm{~d} . \\
1407\end{array}$ & 1452 w & $\begin{array}{c}1448 \text { t.m } \\
14271409\end{array}$ \\
\hline$v(-\mathrm{C}-\mathrm{N}=\mathrm{N}-\mathrm{C}-)$ & $1357 \mathrm{w}$. & $\begin{array}{c}1334 \mathrm{~d} \\
1311\end{array}$ & $1263 \mathrm{~m}$ & $\begin{array}{c}1313 \mathrm{~d}, \mathrm{w} \\
1286\end{array}$ \\
\hline$v\left(\mathrm{M}-\mathrm{N}_{\text {imd. }}\right)$ & - & $405 \mathrm{w}$. & $430 \mathrm{w}$. & $430 \mathrm{w}$. \\
\hline$v\left(M-N_{\text {azo }}\right)$ & - & $366 \mathrm{w}$. & 395 w. & 395 w. \\
\hline$v(\mathrm{M}-\mathrm{Cl})$ & - & $231 s$ & 227sh & 225sh \\
\hline$v\left(\mathrm{M}-\mathrm{NO}_{3}\right)$ & - & - & $\begin{array}{l}1035 m \\
835 w\end{array}$ & - \\
\hline
\end{tabular}

$\mathrm{s}=$ strong, $\mathrm{m}=$ medium, $\mathrm{w}=$ weak, $\mathrm{v}=$ very, $\mathrm{sh}=$ sharp, $\mathrm{br}=$ broad, $\mathrm{d}=\mathrm{doublet} \mathrm{t}=$ triplet. 


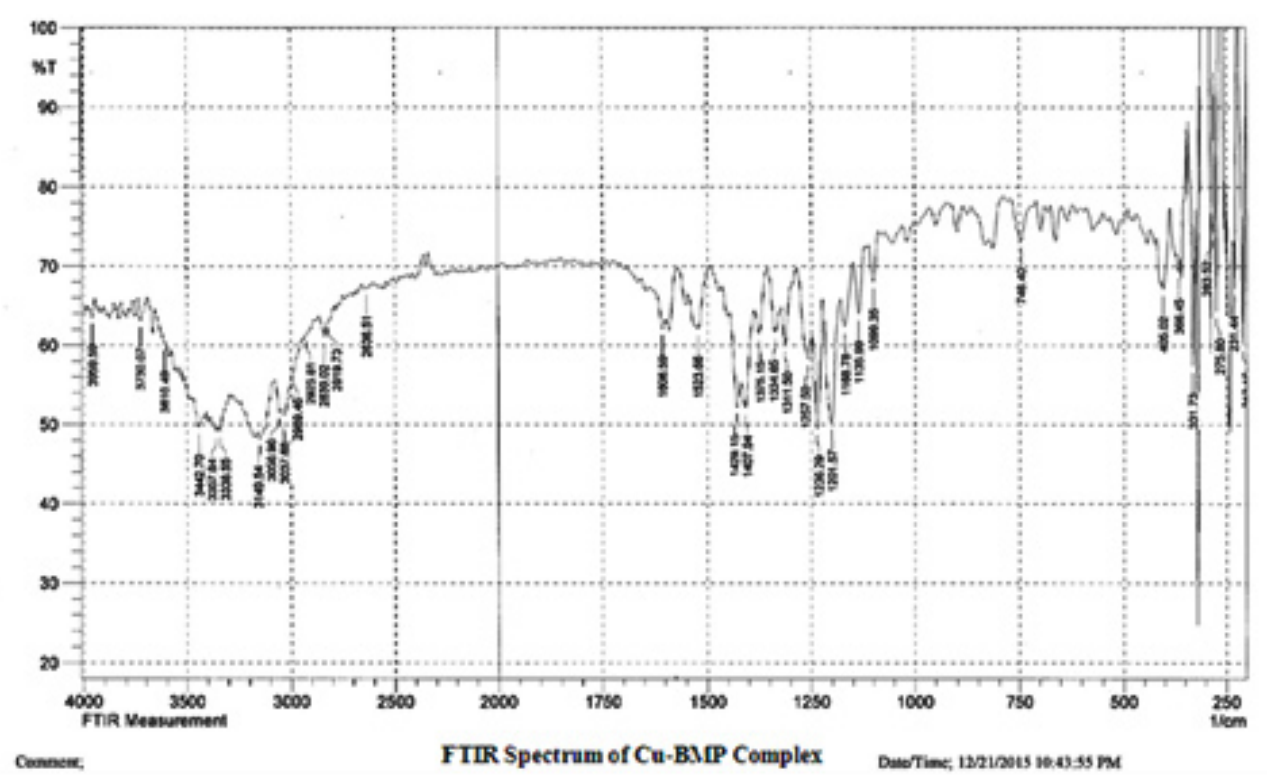

Fig. 11: FTIR spectrum of Cu-BMP Complex

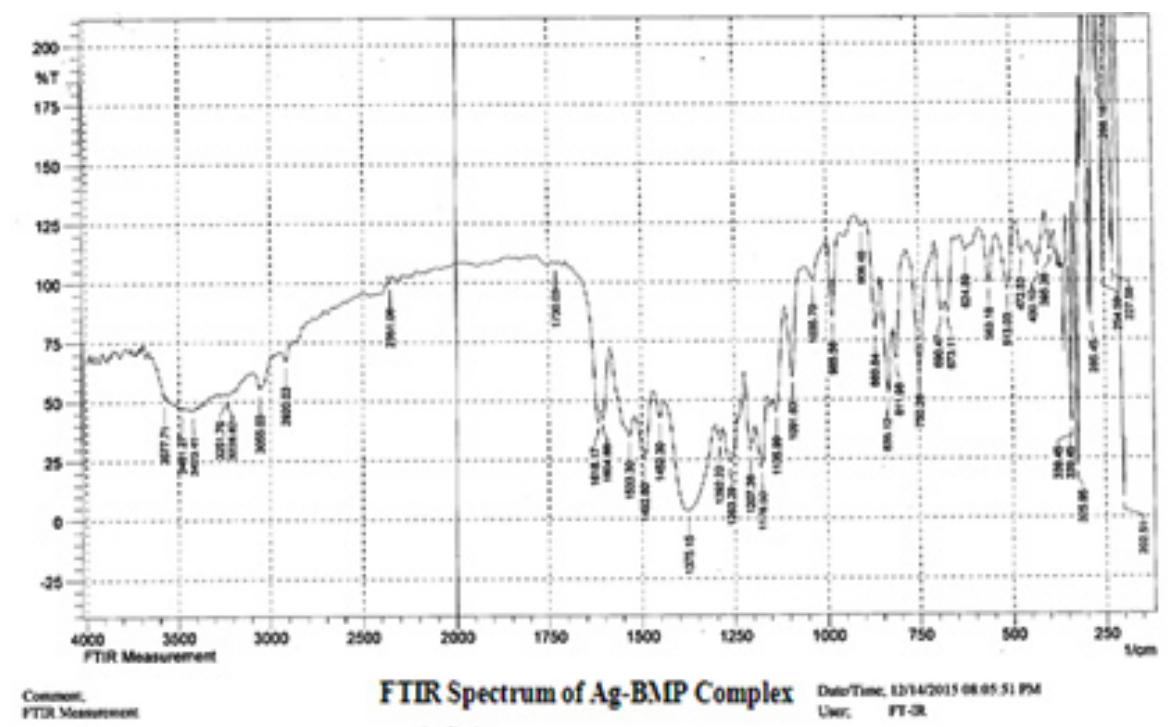

Fig. 12: FTIR spectrum of Ag-BMP Complex

Table 6: ${ }^{1} \mathrm{HNMR}$ spectra of BMP and its Complexes

\begin{tabular}{lccccc}
\hline Compound & $-\mathbf{C O O H}$ & $\mathbf{A r}-\mathbf{H}$ & $\mathbf{- \mathbf { N H } _ { \text { (imd.) } }}$ & $\mathbf{- \mathbf { N H } _ { ( \text { Pro.) } }}$ & Aliph-H \\
& & & & & \\
\hline $\mathrm{BMP}$ & 15.3 & $(8.4-7.2)$ & 5.5 & 2.5 & $(1.1-1.0)$ \\
{$\left[\mathrm{Cu}(\mathrm{BMP})_{2} \mathrm{Cl}_{2}\right]$} & 15.4 & $(7.5-6.8)$ & 5.5 & 2.6 & $(1.2-1.0)$ \\
{$\left[\mathrm{Ag}(\mathrm{BMP})_{2}\right] \mathrm{NO}_{3}$} & 15.4 & $(8.1-7.0)$ & 5.5 & 2.6 & $(1.2-1.0)$ \\
{$\left[\mathrm{Au}(\mathrm{BMP}) \mathrm{Cl}_{2}\right] \mathrm{Cl}$} & 15.4 & $(7.7-7.0)$ & 5.5 & 2.6 & $(1.15-1.0)$ \\
\hline
\end{tabular}


The FTIR spectrum of the ligand (BMP) has been appeared a band at $\left(3440 \mathrm{~cm}^{-1}\right.$ that refer to $\mathrm{i}(\mathrm{O}-\mathrm{H})$ of carboxylic group in proline moiety ${ }^{24}$. Another band was appeared at $\left(3328 \mathrm{~cm}^{-1}\right)$ refer to $v(\mathrm{~N}-\mathrm{H})$ group of proline moiety, these two bands stay unchanged in position in the spectra of prepared complexes mention that there were no coordination through
$\mathrm{N}-\mathrm{H}$ and $\mathrm{COOH}$ group for proline. A doublet bands was prepared at (1620 and 1591) $\mathrm{cm}^{-1}$, these bands have been refer to $v(\mathrm{C}=\mathrm{N})$ in imidazole moiety which were showed changes in shape and shifted to low wave number in the spectra of all complexes due to coordination through N3 for imidazole moiety. The ligand (BMP) also showed triplet bands at (1450,

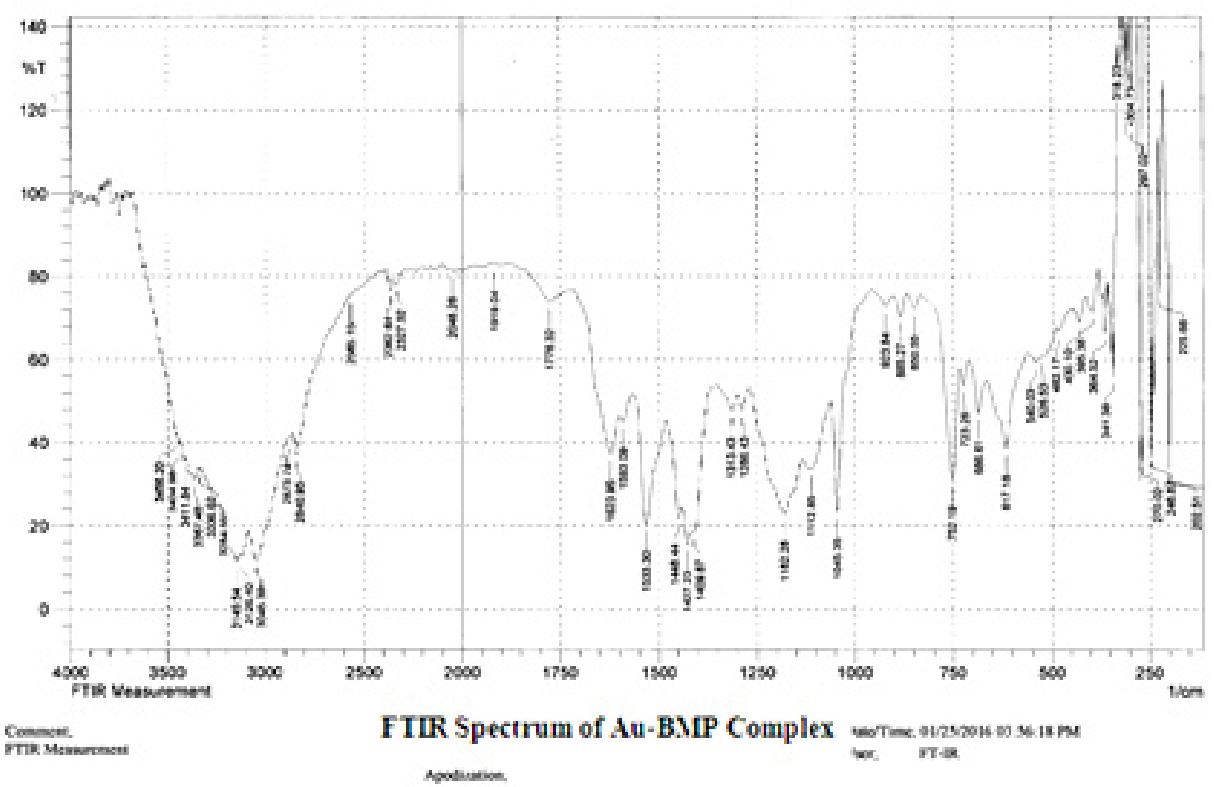

Fig. 13: FTIR spectrum of Au-BMP Complex

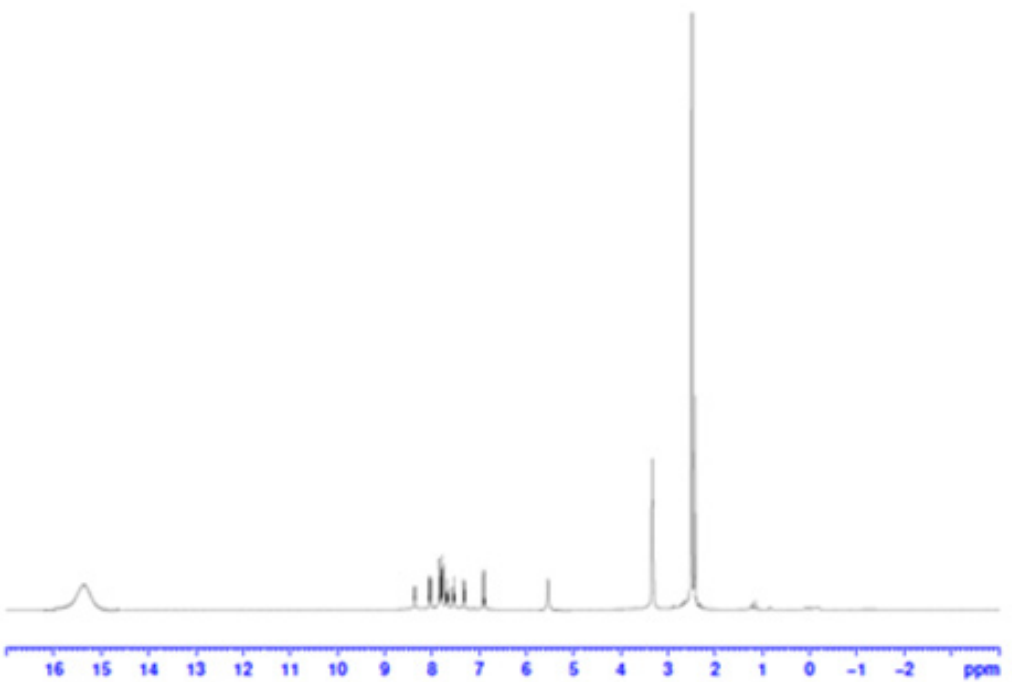

Fig. 14: ${ }^{1}$ HNMR Spectrum for the BMP Ligand 
1448 and 1429$) \mathrm{cm}^{-1}$ which refer to $(\mathrm{N}=\mathrm{N})$ azo moiety ${ }^{25}$. These bands were a specific feature of azo composites. The strength of these band reduced in the complexes spectra, in spite of were shifted to lower frequency by (43) $\mathrm{cm}^{-1}$ for ligand (BMP) which is due to coordination through azo moiety. The band of (-C-N=N-C-) was appeared in the spectrum of the ligand and on complexation was showed a negative shift of order (74-23) $\mathrm{cm}^{-1}$ for ligand (BMP) with changing in intensity and shape, this another indicating the engagement of azo moiety in the coordination with the metal ion. In addition there are new set of bands do not exist in the spectrum of free prepared ligand but display in the spectra of the complexes such as $<(\mathrm{M}-\mathrm{N})_{\mathrm{azo}_{2}},<(\mathrm{M}-\mathrm{N})_{\mathrm{im}},<(\mathrm{M}-\mathrm{Cl})$ in $\mathrm{Cu}$ and Au complexes and $\left(\mathrm{M}-\mathrm{NO}_{3}\right)^{26}$. These mention to the coordination places of the prepared ligand (BMP) with metals ion.

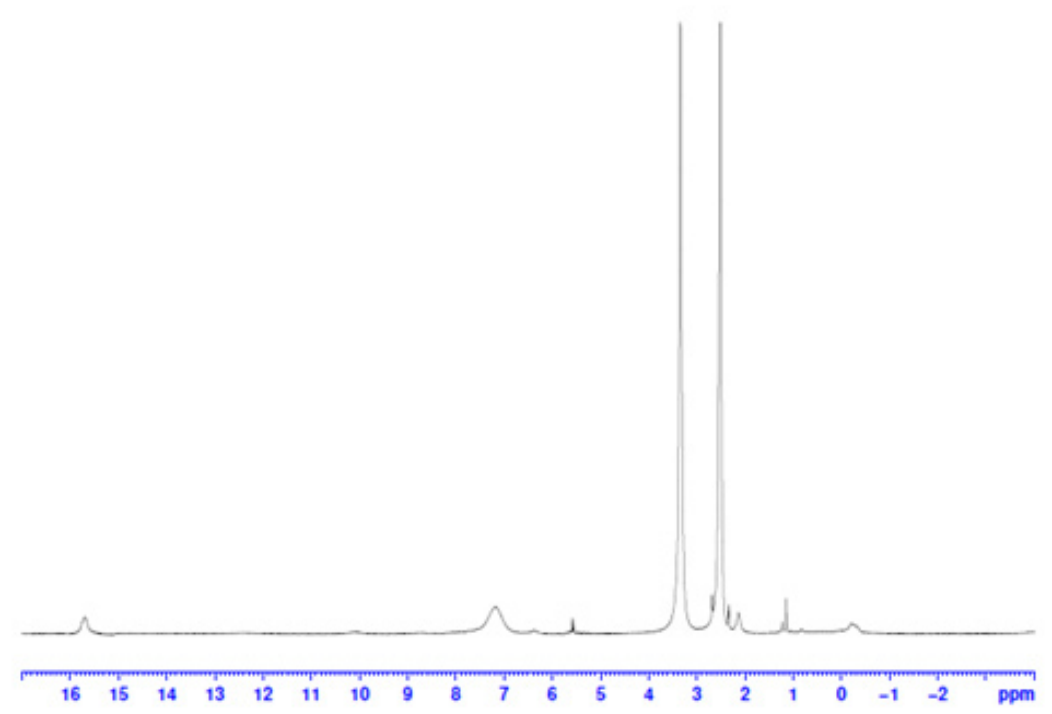

Fig. 15: ${ }^{1}$ HNMR Spectrum for the Cu-BMP Complex

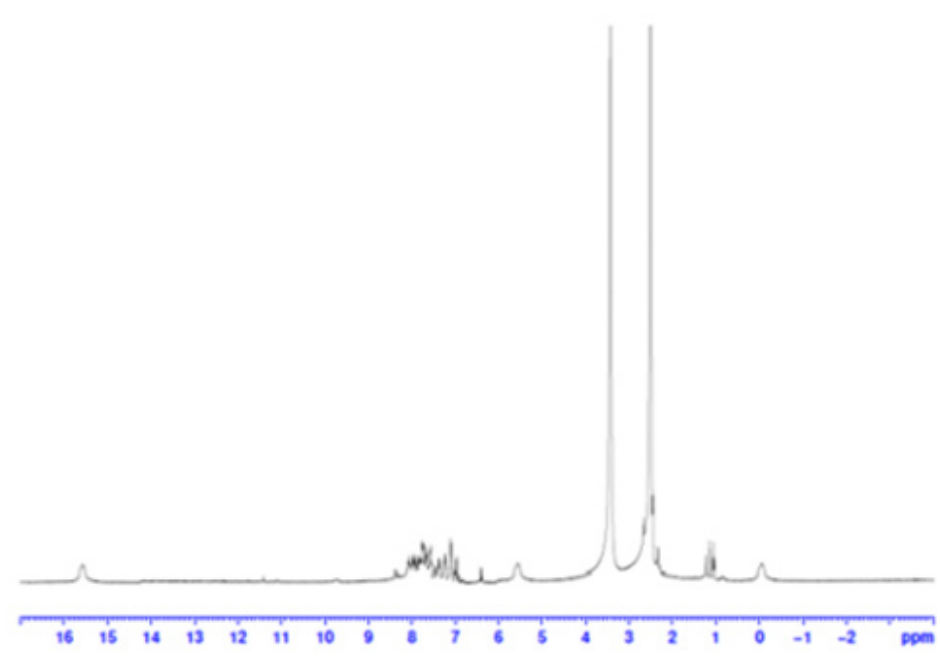

Fig. 16: ${ }^{1} \mathrm{HNMR}$ Spectrum for the Ag-BMP Complex 


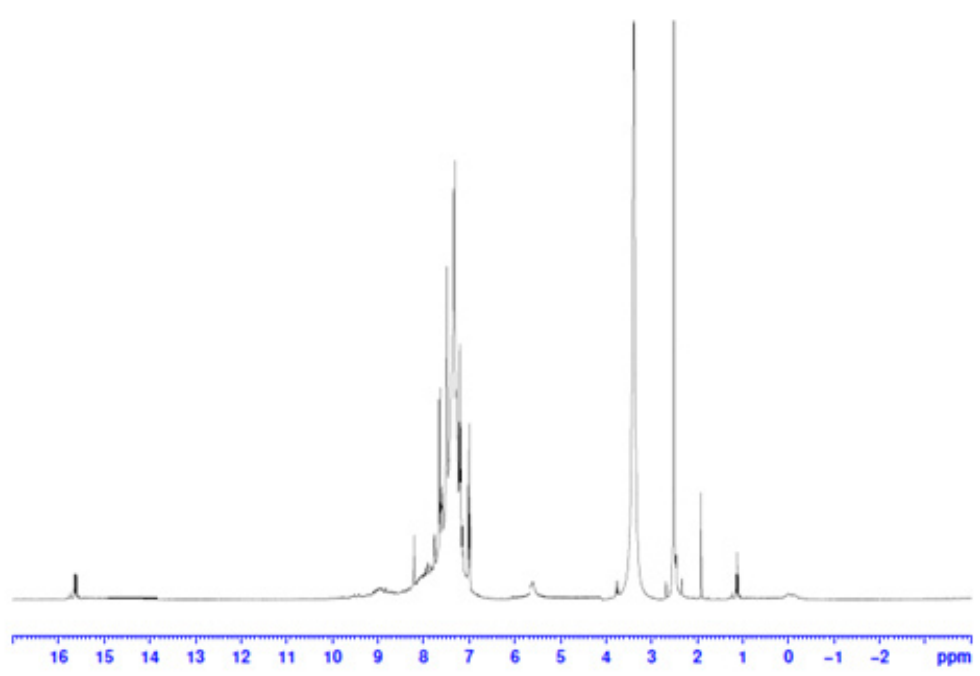

Fig. 17: ${ }^{1}$ HNMR Spectrum for the Au-BMP Complex

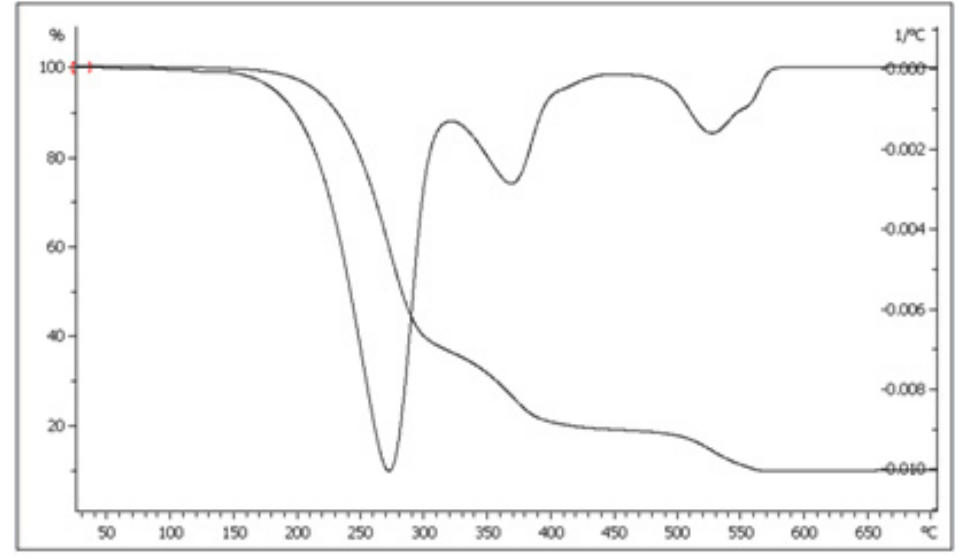

Fig. 18: TG and DTG for BMP Ligand

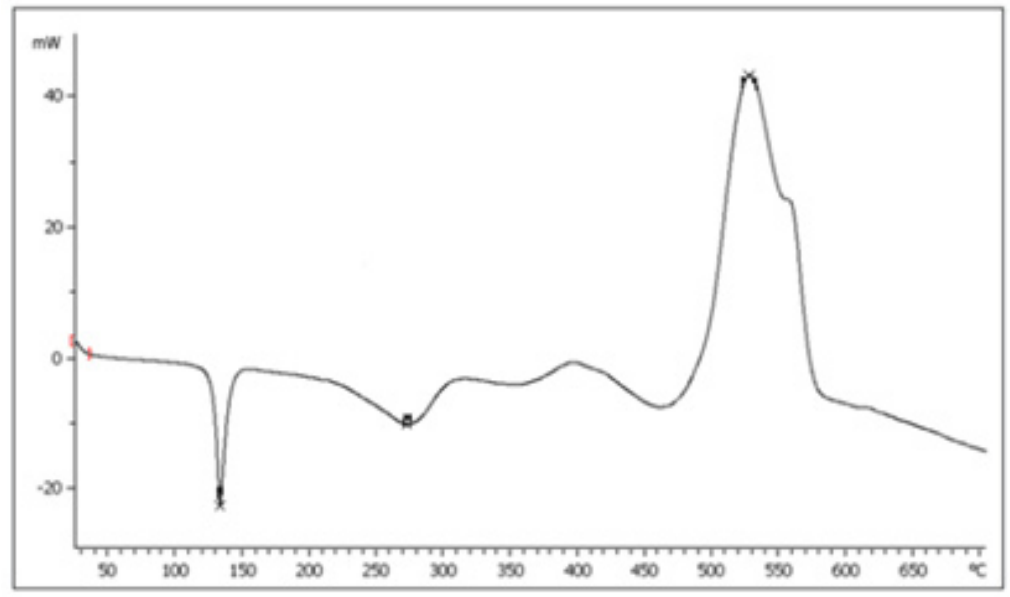

Fig. 19: DSC for BMP Ligand 
${ }^{1} \mathrm{H}$ NMR Spectra of prepared Ligands and Complexes

${ }^{1} \mathrm{H}$ NMR spectra for the prepared ligand (BMP) and its complexes with $) \mathrm{Cu}(\mathrm{II}), \mathrm{Ag}(\mathrm{I})$ and $\mathrm{Au}(\mathrm{III})$ ( in DMSO are shown in (Figures(14-17)) and the peak assignments are explained in Table (6). A singlet peak was appeared at $\delta(15.3) \mathrm{ppm}$ in the spectrum for ligand (BMP) which was due to one proton of free carboxyl moiety in proline ${ }^{27}$. Another singlet signal peak noted at $\delta(5.5) \mathrm{ppm}$ in these spectrum for the ligand (BMP) owing to a proton for $(\mathrm{NH})$ imidazole. These signal peaks don't affect in coordination but stay almost without any chemical shift. The multiple signals noted in the region $\delta(8.4-7.2) \mathrm{ppm}$ for ligand (BMP), these were

Table 7 : The Diameters $(\mathrm{mm})$ of deactivation of two bacteria of the prepared ligand (BMP) and its complexes

\begin{tabular}{llcc}
\hline No. Compound & $\begin{array}{c}\text { G+ } \\
\text { (Staph) }\end{array}$ & $\begin{array}{c}\text { G- } \\
\text { (E-Coli) }\end{array}$ \\
\hline 2 & $\mathrm{BMP}$ & 9 & - \\
4 & {$\left[\mathrm{Cu}(\mathrm{BMP})_{2} \mathrm{Cl}_{2}\right]$} & 10 & - \\
6 & {$\left[\mathrm{Ag}(\mathrm{BMP})_{2}\right] \mathrm{NO}_{3}$} & 15 & 10 \\
8 & {$\left[\mathrm{Au}(\mathrm{BMP}) \mathrm{Cl}_{2}\right] \mathrm{Cl}$} & 11 & 15 \\
9 & Ciprofloxacin & 18.15 & 18.5 \\
10 & Control (C) (DMSO) & 0 & 0 \\
\hline
\end{tabular}

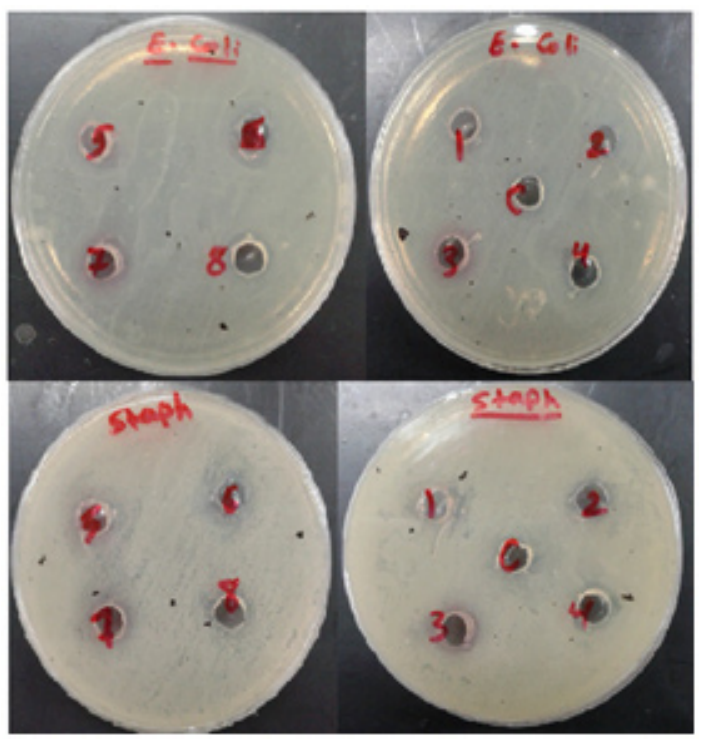

Fig. 20: Antibacterial Activity of prepared Ligand (BMP) and its Complexes denoted to aromatic proton $(4 \mathrm{H})$ for benzene ring in benzimidazole moiety. So little shift happen when complex formation. Furthermore a singlet signal detected in the region $\delta(2.6) \mathrm{ppm}$ for ligand (BMP) which were attributed to $(-\mathrm{NH})$ proton of proline ring ${ }^{27}$, there are no shift were looked in the position in the spectra of the complexes. Also another signal peaks were looked in the spectra of the prepared ligand (BMP) and its complexes which were described in Table (6):

\section{Thermal analysis of the Ligand (BMP)}

Figure (18) have been appeared the thermo gravimetric analysis (TG and DTG) curves for the prepared ligand (BMP) at room temperature up to $900 C^{\circ}$ under helium as inert gas and differential scanning calorimetric (DSC) curve (Figure (19)). The ligand (BMP) with the formula $\left(\mathrm{C}_{12} \mathrm{H}_{13} \mathrm{~N}_{5} \mathrm{O}_{2}\right)$, it showed three decomposition steps at the temperature range $(60-800) \mathrm{C}^{0}$. The first step of $(50-310) \mathrm{C}^{0}$ with mass loss of benzimidazole and azo moiety (60.14\%) (Calculated $60.76 \%$ ) indicated by the DTG peak at (273) $\mathrm{C}^{0}$ with an endothermic peak in DSC curve at (131.4) $\mathrm{C}^{\circ}$. The second temperature of range (310450) $\mathrm{C}^{0}$ the decomposition step assigned to mass loss $(\mathrm{COOH})$ group (18.82\%) (Calculated $17.30 \%)$ and the DTG peak at temperature (370) $\mathrm{C}^{\circ}$ and an endothermic peak at (271.73) $\mathrm{C}^{0}$ in DSC curve. And finally the third step was represented by mass loss for $\left(\mathrm{C}_{2} \mathrm{H}_{3}{ }^{\circ}\right)(11.00 \%)$ (Calculated $\left.11.15 \%\right)$ fragment at temperature range (450-700) $\mathrm{C}^{0}$. The DTG peak was appeared at (555) $\mathrm{C}^{0}$ while the DSC curve was shaw exothermic peak at $\left(527.22 \mathrm{C}^{\circ}\right)$. The

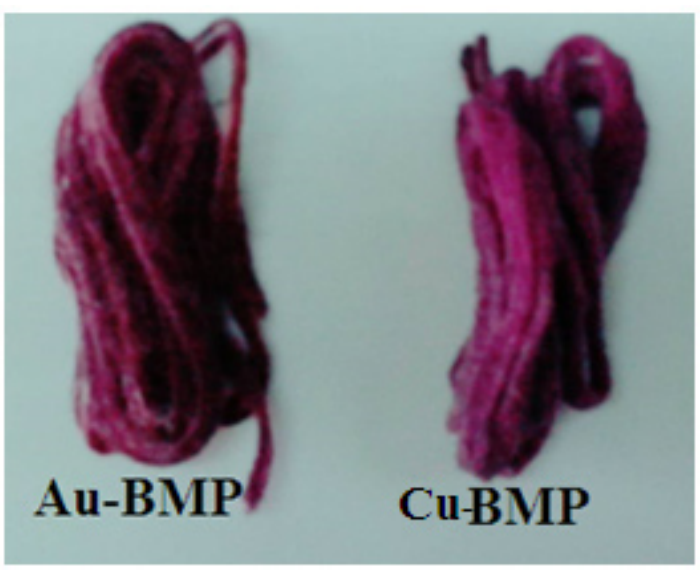

Fig. 21: Dying of prepared Ligand (BMP) and Au-BMP complex 
residue represented the fragment $\left(\mathrm{CH}_{3} \mathrm{~N}^{*}\right)(10.04 \%)$ (Calculated 10.36\%).

$$
\mathrm{C}_{12} \mathrm{H}_{13} \mathrm{~N}_{5} \mathrm{O}_{2} \rightarrow \mathrm{C}_{8} \mathrm{H}_{6} \mathrm{~N}_{4}{ }^{+}+\mathrm{COOH}^{\cdot}+\mathrm{CH}_{3} \mathrm{~N}^{\bullet}+\mathrm{C}_{2} \mathrm{H}_{3} \cdot
$$

\section{Antibacterial Activity of Prepared Ligands and} its Complexes

Two types of bacteria were used in this experiment, Gram Negative Bacteria, Escherichia Coli (E-Coli) and Gram Positive Bacteria, Staphylococcus aureus (Staph) and Ciprofloxacin used as reference.

The ligand (BMP) and its complexes have been appeared low antibacterial activity against Staphylococcus and no antibacterial activity against E-coli exception of Ag-complex had low activity while Au-complex had high activity when comparable with the activity for Ciprofloxacin.
Generally the (ZI) $\mathrm{mm}$ compounds were in the following order;

$$
\text { Ciprofloxacin }>\left[\mathrm{Au}(\mathrm{BMP}) \mathrm{Cl}_{2}\right] \mathrm{Cl}>\left[\mathrm{Ag}(\mathrm{BMP})_{2}\right] \mathrm{NO}_{3}
$$$$
>>\left[\mathrm{Cu}(\mathrm{BMP})_{2} \mathrm{Cl}_{2}\right]>\mathrm{BMP}>(\mathrm{DMSO})
$$

The increased inhibition activity of the metal complexes can be explained on the basis of Tweedy's chelation theory ${ }^{28}$, Further; it increases the delocalization of $\partial$ - electrons over the whole chelate ring 29,30 .

\section{Dying performance}

The dying method of the Cu-BMP and AuBMP complex were studies and applied on acrylic fabric. These set dyes were given colors purple and brown. Figure (21) show a clear color.

\section{REFERENCES}

1. Uhood, J.; Tarik, E.; Howraa, H.; molecules, 2010, 15, 5620-5628.

2. Bulent, K.; Ramazan, A.; Turk J Chem., 2008, 32: $9-17$.

3. Phatok, p.; Jolly, v.s; Sharma, k. p.; Orient. J. Chem., 2009, 16, 493 - 494.

4. Kupradinun, P.; Rienkijakaru, M.; Tanyakaset, M.; Tepsuwan, A.; Kusamran, W. R.; Asian Pacific J. Cancer Prevention, 2008, 3, , 5560.

5. Mehdi, R.T.; Ali, A. M.; National Journal of Chemistry, 2006, 20, 504-546.

6. Al-adely, K. J.; Ali, A. M.; Mehdi, R. T.; National Journal of Chemistry, 2010, 38, 311-324.

7. Weaver, M. A.; Shuttleworth, L.; Dyes and Pigments, 2007, 3, 81-121.

8. Sharma, K. P.; Jolly, V.S.; Phatak, P.; Journal of Ultra Scient. Phys. Sci., 2008, 10, 263 - 266.

9. Majed, H.; Muzad, Ta.; AL-Zamili, F.; Hyder, K.S.; J.Thi.Qar. Sci., 2008, 2, 122-128.

10. Dmitrienko, S. G.; Khatuntseva, L.N.; Apyari, V. V.; Zolotov, Yu.A.; Journal of Chem. Anal., 2005, 50, 327-335.

11. Mirkhani, V.; Tangestaninejad, S.; Moghadam, M.; Habibi M. H.; Vartooni, A.; J. Iran. Chem. Soc., 2009, 6, 578-586.

12. Bakhsh, A.D; Rufchahi, Y.D.; Orient. J. Chem.,
2009, 25, $41-45$.

13. Gavali, L. V.; Hankarep, P. P.; Journal of Physical Sciences, 2007, 11, 147-155.

14. Sarkar, D.; Kumar, A.; Mandal, T.; Elsevier, 2013, 115, 421-425.

15. Mohamed, G.G.; Omar, M.M.; Handy, A.N.; Turk. Journa.Chem. 2006, 30, ,61-382.

16. Masoud, S.; Amine, A.; Alaa, E.; Osama, K.; Journal Coord. Chem., 2006, 56,725

17. Masoud, M.S.; Mohamed, G. B.; Abdul-Razak, Y. H.; Ali, A. E.; Journal Korean. Chem. Soc., 2007, 46, 99-110.

18. Mohanad, H. N.; Journal of Kerbala University, 2011, 9, 189-198.

19. Jarad, A.J.; Zainab, S. K.; International Journal of Humanities, Arts, Medicine and Sciences. 2015, 3, 197-210.

20. Cao, H.W; Zhao, J.F.; Elsevier, 2006, 76,1-6.

21. Lever ABP "Inorganic Spectroscopy";, 2nd -Elsevier Science Publisher, Amsterdam. 1984, 198- 215.

22. Yohannes, E.; Chandravanshi, B.S.; Gridasova, R.K.; African Journals Onlin, 2005, 9, 1-8

23. Byabartta, P.; African Journal of Pure and Applied Chemistry, 2009, 3, 177-182.

24. Lobana, T.S.; Sharma, R.; Bawa, G.; Khanna, G. G.; European Journal of Inorganic 
Chemistry,2009,253, 977-1055.

25. Mahalingam, V.; Karvembu, R.; Chinnusamy, V.; Natavajar, K.; Malaysian Journal of Fundamental \& Applied Sciences, 2006, 64, 886-890.

26. Gupta, Y.K.; Agarwal; S.C.; Madnawat, S.P.; Narain, R.; Research Journal of Chemical Sciences, 2012, 2, $68-71$

27. Silverstein, R.M.; Webster, F.X.; 1996, Spectrometric identification of organic compounds $6^{\text {th }}$ Ed. Wiley and Sons. New York.

28. Tweedy , BG. J. Phytopathology. 1964 ; 55, 910-914.
29. Taghreed, H. Al-Noor, Lekaa, K. Abdul Karim," Synthetic, Spectroscopic And Antibacterial Studies Of $\mathrm{Co}(\mathrm{Ii}), \mathrm{Ni}(\mathrm{Ii}), \mathrm{Cu}(\mathrm{Ii}), \mathrm{Zn}(\mathrm{li}), \mathrm{Cd}(\mathrm{Ii})$ And $\mathrm{Hg}$ (li), Mixed Ligand Complexes Of Trimethoprime Antibiotic And Anthranilic Acid", TOFIQ Journal of Medical Sciences; 2016, 3,: 64-75.

30. Taghreed . H. Al-Noor, Khalid F Ali, Amer J. Jarad and aliea. S .kindeel, "Synthesis, spectral and antimicrobial activity of mixed ligand complexes of $\mathrm{Co}(\mathrm{II}), \mathrm{Ni}(\mathrm{II}), \mathrm{Cu}(\mathrm{II})$ and $\mathrm{Zn}(\mathrm{II})$ with Anthranillic Acid and Tributylphosphine" , Journal of hemistry and Materials ;2013, 3:126-139. 